\title{
Assessments of occurrence and distribution of mammals in forests of the Garden Route National Park based on camera trapping
}

\author{
Authors: \\ Nicholas Hanekom ${ }^{1}$ \\ Rodney M. Randall ${ }^{1}$ \\ Affiliations: \\ ${ }^{1}$ South African National \\ Parks, Sedgefield, South \\ Africa \\ Correspondence to: \\ Nicholas Hanekom \\ Email: \\ nick1hanekom@gmail.com \\ Postal address: \\ PO Box 176, Sedgefield 6573, \\ South Africa \\ Dates: \\ Received: 16 Oct. 2014 \\ Accepted: 24 July 2015 \\ Published: 30 Oct. 2015 \\ How to cite this article: \\ Hanekom, N. \& Randall, \\ R.M., 2015, 'Assessments of \\ occurrence and distribution \\ of mammals in forests of the \\ Garden Route National \\ Park based on camera \\ trapping', Koedoe 57(1), \\ Art. \#1257, 7 pages. http:// \\ dx.doi.org/10.4102/koedoe. \\ v57i1.1257

\section{Copyright:} \\ (C) 2015. The Authors. \\ Licensee: AOSIS \\ OpenJournals. This work is \\ licensed under the Creative \\ Commons Attribution \\ License.
}

Read online:

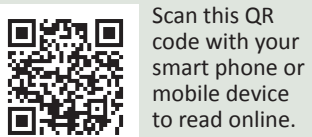

Eleven mammal census sites were selected in four different Afrotemperate Forest types in the Garden Route National Park, South Africa. At each site, an array of eight camera traps was deployed along trails for between 28 and 45 days. Based on accumulation curves, this was generally sufficient for recording most of the focal mammal species at each site. Only 12 mammal ( $\geq 1 \mathrm{~kg}$ ) species were recorded, two of which were primarily wetland species. The most widely captured taxa were bushbuck, Tragelaphus scriptus (all 11 sites); and caracal, Caracal caracal (10 sites). The most frequently photographed species were bushbuck (40\%) and chacma baboon, Papio ursinus (22\%). The number of species and total capture rates did not differ $(P>0.10)$ between dry (scrub and high) forests and moist (medium-moist to wet) forests, or between small $\left(<41 \mathrm{~km}^{2}\right)$ forests and a large forest complex. However, at species level, the capture rates of caracal and vervet monkey, Chlorocebus pygerythus; were significantly lower $(P \leq 0.05)$ in the large forest complex than in small forests, whilst those of bushpig, Potamochoerus larvatus; were higher. Trapping cycles of between 28 and 45 days, which recorded the highest number of threatened and protected South African species, were from small forests.

Conservation implications: The role of small forests in the conservation of mammals in the Garden Route National Park should be investigated further, because relatively high numbers of threatened and protected South African mammal species were recorded in these locations.

\section{Introduction}

Terrestrial mammal inventories for various sections of the large, spatially fragmented Garden Route National Park (GRNP) (Figure 1) were compiled primarily from field records, observations and trappings conducted in the coastal sections (Crawford 1982; Robinson 1976; Von Breitenbach 1974; Whitfield, Allanson \& Heinecken 1983). These data were supplemented by studies of individual species, such as bushbuck, Tragelaphus scriptus (Odendaal \& Bigalke 1979); bushpig, Potamochoerus larvatus (Seydack \& Bigalke 1992); blue duiker, Philantomba monticola (Hanekom \& Wilson 1991); and the African elephant, Loxodonta africana (Seydack, Vermeulen \& Huisamen 2000). Additional data were obtained from population monitoring through faecal pellet counts (Seydack, Huisamen \& Kok 1998) and a camera trap study in the Goudveld State Forest (Seydack 1984).

The use of camera traps for studying terrestrial mammals has become increasingly popular in recent years, as technology has improved and equipment costs have declined (Kucera \& Barrett 2011; Tobler et al. 2008). Applications include compiling species inventories (e.g. Azlan \& Lading 2006; Srbek-Araujo \& Chiarello 2005; Trolle 2003), studying activity patterns (Azlan \& Sharma 2006; Gómez et al. 2005) and habitat relationships (Goulart et al. 2009; Jácomo, Silveira \& DinizFilho 2004), and estimating animal densities (e.g. Chapman \& Balme 2010; Karanth \& Nichols 1998; Karanth et al. 2006; Kelly et al. 2008).

Compared to track and transect censuses, camera traps can produce satisfactory results in the inventory of medium- to large-sized mammals (Silveira, Jácomo \& Diniz-Filho 2003; Tobler et al. 2008). When used together, such methods can be complementary, because camera traps can be deployed in most field conditions and are efficient methods of recording nocturnal species (Silveira et al. 2003; Srbek-Araujo \& Chiarello 2005).

The advantages of camera traps include the accuracy of species identification, the detection of nocturnal and diurnal species, and the ability of accumulating data over large areas with relatively little effort (Silveira et al. 2003; Sollmann et al. 2013). The aim of this study was to undertake camera trapping in order to supplement the mammal inventory list of the GRNP and assess the 


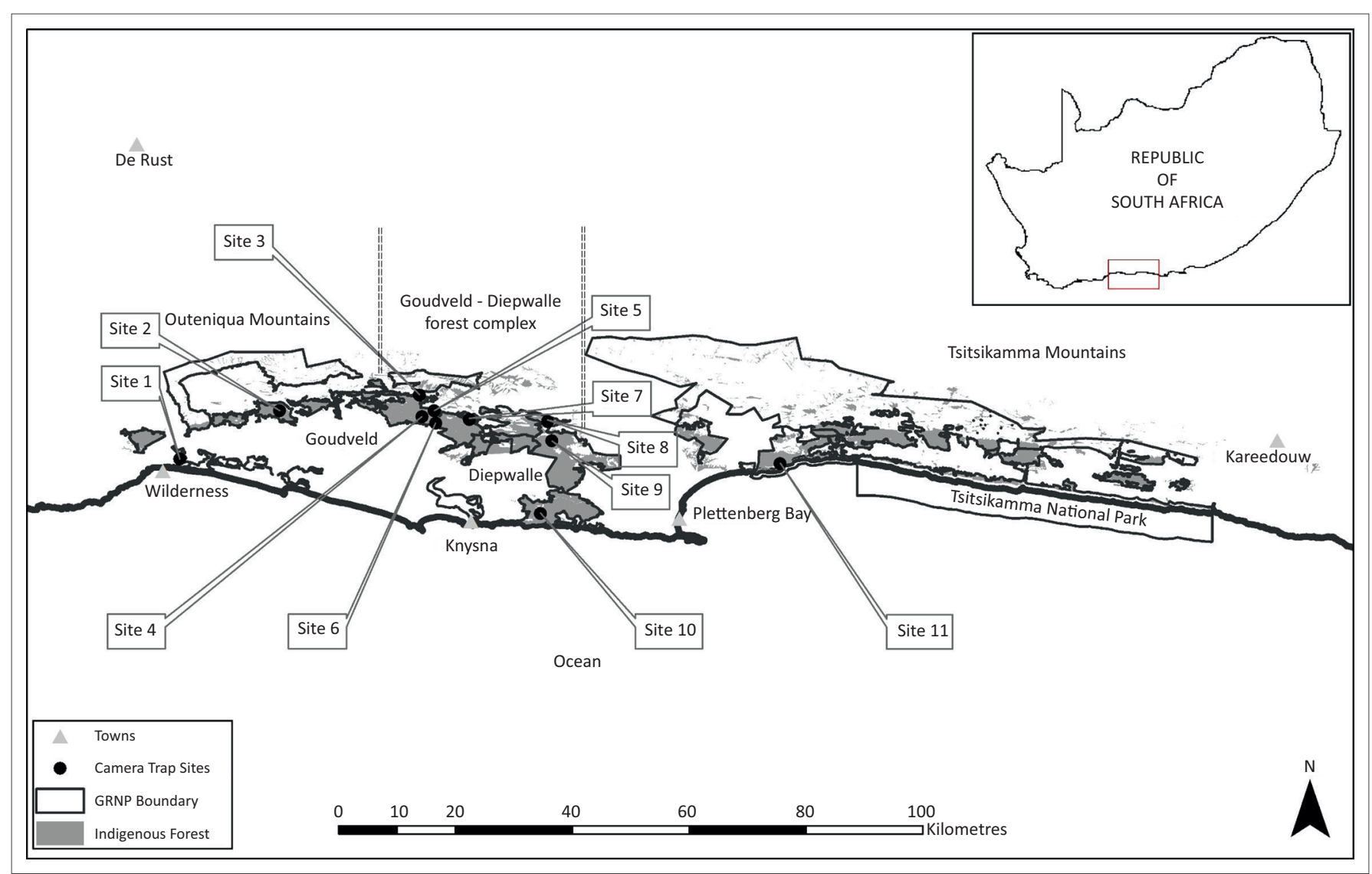

Source: Forestry section, South African National Parks

FIGURE 1: Map of the Southern Cape showing the location of the Garden Route National Park, its indigenous forests and camera trap sites.

distribution and capture rates of mammals within forests of varying types (dry to wet) and sizes. These data could assist in identifying priority conservation areas in the park.

\section{Methods}

The GRNP is situated between the sea and the Outeniqua and Tsitsikamma mountains of the Southern Cape. It is spatially fragmented and consists of a mosaic of protected areas, which extend over some $150 \mathrm{~km}$ in an east-west direction and $40 \mathrm{~km}$ on a north-south axis. The altitude ranges between $0 \mathrm{~m}$ and $1675 \mathrm{~m}$ above sea level. The climate is mild and rainfall occurs throughout the year (Kruger 2007). Precipitation generally increases with altitude (Bond 1981), potentially varying from approximately $650 \mathrm{~mm}$ along the coast to about $1100 \mathrm{~mm}$ in the mountains (Fijen \& Kapp 1995).

Most of the 43000 ha of forest in the park is classified as Southern Cape Afrotemperate Forest (Mucina \& Rutherford 2006) and is bordered by indigenous fynbos, pine plantations and farmlands. This Afrotemperate Forest occurs from sea level to an altitude of approximately $1000 \mathrm{~m}$ a.s.l. (Mucina \& Rutherford 2006). As a consequence of variations in topography, soils and microclimate, differences occur in the composition, abundance and height of tree species (Von Breitenbach 1974). Following a gradient from the dry littoral zone to the wet mountain ranges, Von Breitenbach (1974) described eight different forest types. This system has been used by the forestry section of South African National Parks to classify indigenous forest compartments for management purposes. This classification of the forests was used in the selection of camera trap sites and the estimation of forest sizes.

Between two and five sampling sites, with limited human activity and adequate trails, were identified in each of the four more common forest types found in the park, namely wet high-forest, medium-moist to moist high-forest, dry highforest and very dry scrub-forest. A total of 11 sites were selected (Figure 1). At each site, an array of eight cameras, consisting of four Bushnell Trophy Cams (with infrared flash) and four Cuddeback Capture cameras (with incandescent flash), was deployed for between 28 and 45 days. The exception was Site 7 , where, as a consequence of certain camera malfunction and additional research objectives, a combination of six Bushnell cameras and two Cuddeback cameras (less sensitive to being triggered by small mammals, such as genets [Randall \& Hanekom 2014]) were deployed for 114 days.

Camera positions were geo-referenced using a Garmin GPSMAP 60CSx, and each camera was positioned at least $100 \mathrm{~m}$ apart, but where possible between $200 \mathrm{~m}$ and $300 \mathrm{~m}$ apart. Cameras were erected to photograph across trails because the highest captures were recorded here during field trials. At each site, a metal fencing pole was driven into the ground and a camera secured to it in such a manner that the lens was approximately $35 \mathrm{~cm}$ above the ground and about $3 \mathrm{~m}$ away from the centre of the trail. No bait or lures were used to attract animals to the cameras. 
Where it was judged that, based on the location and time of captures as well as the size and marking of the animals, multiple photographs of the same individual were taken within one hour of each other within the entire camera array, these photographs were regarded as a single capture (Tobler et al. 2008). This mitigated the effect of multiple captures resulting from instances where animals walked passed several cameras, or spent extended periods in front of one or more cameras.

Trapping was conducted between March 2010 and January 2011, except for Site 7 (between August and December 2012) and Site 8 (between October and November 2013). The cumulative number of species detected with increasing sampling effort was determined for each of the 11 sites surveyed, and where the data from two or more sites showed similar rates of increase, the data were pooled and the mean values taken.

At Sites 7-10, additional sampling was done between January 2011 and July 2012, as part of another survey. At each site, monthly trappings were done at 24 additional camera locations spread over more than $2.3 \mathrm{~km}$ and located $15 \mathrm{~m}-$ $35 \mathrm{~m}$ away from access paths in undisturbed forest. This work provided supplementary trapping coverage as well as capture rates for off-trail areas.

The normality and homogeneity of the variance for the capture data were checked using Kolmogorov-Smirnov and Bartlett's tests (Zar 1984). Where they were not realised, nonparametric statistical tests were used. The aggregated capture rates and species counts across all cameras on trails at each site from the four dry (high and scrub) forests were compared to those from the seven moist (medium-moist to wet) high forests using the Mann-Whitney $U$ Test (Zar 1984) and the computer program STATGRAPHICS (Statistical Graphic
Corporation 1989). Similar comparisons were conducted between capture data recorded in small forests $\left(<41 \mathrm{~km}^{2}\right)$ and those in the large $\left(160 \mathrm{~km}^{2}\right)$ Goudveld-Diepwalle forest complex, but not between off-trail and on-trail data, because of the small sample size $(n=4)$.

\section{Results}

At most forest sites, with the exception of Sites 5 and 8, the cumulative number of species recorded using a sampling effort of 223-360 camera trap days appeared to level off near an upper asymptote. At Site 7, no additional species were recorded when the sampling was extended to 912 trap days (Figure 2). During the entire survey (3438 trap days and 88 trap sites), only 12 mammal species ( $\geq 1 \mathrm{~kg}$ ) were recorded. Two of them - the African clawless otter, Aonyx capensis; and marsh mongoose, Atilax paludinosus - are associated with wetlands rather than forests (Skinner \& Chimimba 2005) and were photographed on only one occasion on the trails (Table 1).

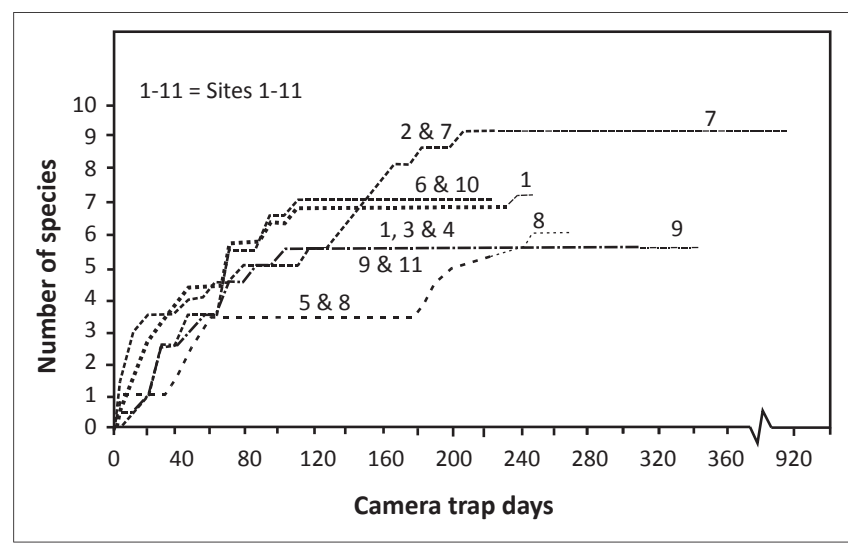

FIGURE 2: Cumulative numbers of species detected with increasing sampling effort at each forest site, with broad lines representing combined values from two or more sites and thin lines representing a single site.

TABLE 1: Forest characteristics, sampling effort and numbers of photographic captures (expressed as records per 1000 trap days) of the different species recorded at 11 sites during a general survey (and at Site 7 during extended sampling), as well as the percentage contribution of each species to the overall total.

\begin{tabular}{|c|c|c|c|c|c|c|c|c|c|c|c|c|c|}
\hline Factors & Site 1 & Site 2 & Site 3 & Site 4 & Site 5 & Site 6 & Site 7 & Site 8 & Site 9 & Site 10 & Site 11 & All site (Mean) & Contr. $(\%)$ \\
\hline \multirow[t]{2}{*}{ Forest type } & V dry & Moist & Wet & Moist & Wet & Dry & Moist & Moist & Moist & Dry & V dry & - & - \\
\hline & Scrub & High & High & High & High & High & High & High & High & High & Scrub & - & - \\
\hline Forest cover $\mathrm{km}^{2}$ & 6.4 & 12.2 & 160.5 & 160.5 & 160.5 & 160.5 & 160.5 & 160.5 & 160.5 & 39.9 & 13.9 & - & - \\
\hline Effort (trap days) & 224 (s) & 224 (s) & $222(w)$ & $256(w)$ & $224(w)$ & $224(w)$ & $360(w)(912)$ & $272(s)$ & $360(s)$ & $224(w)$ & $296(s)$ & - & - \\
\hline Bushbuck & 45 & 103 & 59 & 258 & 98 & 76 & $69(43)$ & 96 & 83 & 22 & 196 & 100 & 39.5 \\
\hline Chacma baboon & 0 & 4 & 0 & 449 & 9 & 0 & $67(51)$ & 0 & 0 & 89 & 0 & 56 & 22.1 \\
\hline S. Afr. I-s genet & 54 & 0 & 14 & 20 & 9 & 0 & $111(84)$ & 96 & 19 & 27 & 14 & 33 & 13.0 \\
\hline Bushpig & 0 & 0 & 14 & 86 & 13 & 27 & $17(11)$ & 77 & 22 & 4 & 17 & 25 & 9.9 \\
\hline Caracal & 13 & 22 & 0 & 8 & 4 & 4 & $22(13)$ & 4 & 3 & 22 & 61 & 15 & 5.8 \\
\hline Blue duiker & 13 & 9 & 5 & 12 & 9 & 0 & $0(0)$ & 29 & 0 & 31 & 0 & 10 & 3.9 \\
\hline Cape porcupine & 27 & 18 & 0 & 0 & 0 & 9 & $11(5)$ & 0 & 0 & 0 & 7 & 7 & 2.6 \\
\hline Honey badger & 4 & 4 & 5 & 4 & 0 & 0 & $3(1)$ & 11 & 8 & 9 & 0 & 4 & 1.7 \\
\hline Vervet monkey & 0 & 4 & 0 & 0 & 0 & 0 & $3(1)$ & 0 & 0 & 9 & 3 & 2 & 0.7 \\
\hline Leopard & 4 & 4 & 0 & 0 & 0 & 0 & $6(6)$ & 0 & 0 & 0 & 0 & 1 & 0.5 \\
\hline Marsh mongoose & 0 & 4 & 0 & 0 & 0 & 0 & $0(0)$ & 0 & 0 & 0 & 0 & $<1$ & 0.1 \\
\hline African c-l otter & 0 & 0 & 0 & 0 & 0 & 4 & $0(0)$ & 0 & 0 & 0 & 0 & $<1$ & 0.1 \\
\hline Total & 160 & 172 & 97 & 837 & 142 & 120 & 309 (215) & 313 & 135 & 213 & 298 & 254 & 100.0 \\
\hline Species & 7 & 9 & 5 & 6 & 6 & 5 & 9 (9) & 6 & 5 & 8 & 6 & 7 & - \\
\hline
\end{tabular}

V dry, very dry; Contr., contribution; S. Afr. I-s genet, South African large-spotted genet; African c-I otter, African clawless otter; (s), summer; (w), winter. 
The most widely captured species were bushbuck (all 11 sites); caracal, Caracal caracal (10 sites); South African largespotted genet, Genetta tigrina; and bushpig, Potamochoerus larvatus (9 sites). The biggest contributors to the overall captures were bushbuck (40\%), chacma baboon, Papio ursinus (22\%); South African large-spotted genet (13\%) and bushpig (10\%) (Table 1). Three threatened and protected South African species - blue duiker, leopard, Panthera pardus; and honey badger, Mellivora capensis - together comprised approximately $6 \%$ of captures (Table 1 ).

Photographic captures varied substantially between forests, and three of the seven sites surveyed in the large GoudveldDiepwalle forest complex (i.e. Site 3 [wet forest], Site 6 [dry forest] and Site 9 [moist forest]) had both the lowest numbers of species (5) and total capture rates $(\leq 135$ captures $/ 1000$ trap days) recorded in this survey (Table 1). Despite this, the median and interquartile range of the number of species and total capture rates recorded in the Goudveld-Diepwalle forest complex did not differ significantly $(U=1.45$ and 0.28 , $d f=7.4, P>0.10)$ from those of small $\left(<41 \mathrm{~km}^{2}\right)$ forests (Table 1$)$. At species level, however, the capture rates of caracal and vervet monkey, Chlorocebus pygerythus, were significantly lower $(P \leq 0.05)$ in the large forest complex than in small forests $(U=2.21$ and $1.98, d f=7.4)$, whilst those of bushpig were higher $(U=2.09, d f=7.4)$. Conversely, no significant differences were recorded between the capture rates from dry (high and scrub) forests and those from moist (mediummoist to wet) high forests $(U<1.26, d f=7.4, P>0.10)$.

The additional and more extensive (> 750 trap days) off-trail trapping at Sites 7-10 recorded a similar trend to that of the on-trail survey, in that both the number of species and total capture rates at Site 9 were lower (> 15\%) than at the other three sites (Table 2). At all four sites, the total capture rates of the off-trail cameras were approximately half $(45 \%-54 \%)$ of those of the on-trail ones, consistently capturing fewer caracal and frequently (75\% of the sites) fewer bushbuck, bushpig, genet and honey badger (Table 2). The median number of species recorded off-trail was similar to that captured on-trail, but the composition differed, adding one or two more species to each site (Table 2).

\section{Discussion}

In camera trap studies for inventories of medium- to large bodied species, an enormous amount of survey effort is usually required to capture all the cryptic, rare or habitatspecific mammal species (Tobler et al. 2008). For example, 1035 trap days recorded only $57 \%$ of the total number of species (28) in Emas National Park in Brazil (Silveira et al. 2003); 1849 trap days captured $81 \%$ of the 21 species in Brazil's Atlantic Forest (Srbek-Araujo \& Chiarello 2005); and 2340 trap days registered $86 \%$ of the 28 species in the Peruvian Amazon (Tobler et al. 2008).

The on-trail trapping effort used at each site in this study was considerably less (approximately $0.35-0.15$ times) than the above-mentioned values (Table 1), and would have been insufficient in recording the full range of species in each forest, especially those with extensive home ranges (e.g. leopard) or specific habitat preferences (e.g. African clawless otter). The supplementary off-trail trapping at Sites 7-10 recorded on average one additional species at each site, but none of these were new species records for the study (Table 2).

The total number (12) of mammal species ( $\geq 1 \mathrm{~kg}$ ) recorded during on-trail trapping (3438 trap days) was comparable with that noted over a three-year camera trapping census (13) (approximately 6480 trap days) of 600 ha of forest (incorporating Sites 4 and 5) in the Goudveld State Forest near the centre of the study area (Seydack 1984). However, the species composition differed. Seydack (1984) did not

TABLE 2: Forest characteristics, sampling effort and numbers of photographic captures (expressed as records per 1000 trap days) of the different species recorded at Sites 7-10 during on-trail and off-trail trapping.

\begin{tabular}{|c|c|c|c|c|c|c|c|c|}
\hline Factors & Site 7 & Site 7 & Site 8 & Site 8 & Site 9 & Site 9 & Site 10 & Site 10 \\
\hline Survey & On-trail & Off-trail & On-trail & Off-trail & On-trail & Off-trail & On-trail & Off-trail \\
\hline Forest type & Moist & Moist & Moist & Moist & Moist & Moist & Dry & Dry \\
\hline Forest cover $\mathrm{km}^{2}$ & 160.5 & 160.5 & 160.5 & 160.5 & 160.5 & 160.5 & 39.9 & 39.9 \\
\hline Effort (trap days) & 360 & 810 & 272 & 744 & 360 & 758 & 224 & 864 \\
\hline Bushbuck & 69 & 19 & 96 & 36 & 83 & 32 & 22 & 28 \\
\hline Chacma baboon & 67 & 68 & 0 & 32 & 0 & 8 & 89 & 10 \\
\hline Bushpig & 17 & 30 & 77 & 22 & 22 & 8 & 4 & 2 \\
\hline Caracal & 22 & 1 & 4 & 0 & 3 & 0 & 22 & 1 \\
\hline Blue duiker & 0 & 6 & 29 & 43 & 0 & 0 & 31 & 25 \\
\hline Cape porcupine & 11 & 0 & 0 & 0 & 0 & 0 & 0 & 0 \\
\hline Honey badger & 3 & 0 & 11 & 19 & 8 & 0 & 9 & 2 \\
\hline Vervet monkey & 3 & 0 & 0 & 0 & 0 & 1 & 9 & 10 \\
\hline Leopard & 6 & 0 & 0 & 0 & 0 & 0 & 0 & 5 \\
\hline African c-l otter & 0 & 0 & 0 & 0 & 0 & 0 & 0 & 0 \\
\hline No of species & 9 & 7 & 6 & 7 & 5 & 5 & 8 & 9 \\
\hline Total & 309 & 168 & 313 & 161 & 135 & 70 & 213 & 95 \\
\hline
\end{tabular}

S. Afr. I-s genet, South African large-spotted genet; African c-I otter, African clawless otter; No, number. 
capture vervet monkey or African clawless otter, but he did record ( $\leq 2$ captures) Cape grysbok, Raphicerus melanotis; Cape grey mongoose, Galerella pulverulenta; and rock hyrax, Procavia capensis. These three mammals are not true forest species, but utilise forest margins and very dry scrub forests to varying degrees (Crawford, Crawford \& Crawford 1983; Robinson 1976; N.H. personal observation 1988).

The only other species known to frequent these forests is the African elephant (Seydack et al. 2000), but it occurs in extremely low numbers (Eggert, Patterson \& Maldonado 2007). Consequently, there are verified records for only 16 mammal species ( $\geq 1 \mathrm{~kg}$ ) utilising the forests of the GRNP, which grow on nutrient-poor soils (Van Daalen 1984) and have a low herbivore carrying capacity (Odendaal \& Bigalke 1979; Seydack et al. 2000).

Eleven $(69 \%)$ of these species, including the African clawless otter and marsh mongoose, were recorded in the south coast forests of the Transkei region, where chacma baboon and honey badger were apparently absent (Hayward et al. 2005). However, the study provided no evidence of serval, Leptailurus serval, and African wildcat, Felis silvestris lybica, which are listed by Von Breitenbach (1974) as species found in the Southern Cape forests.

The species that contributed most to the captures in this study were bushbuck (40\%), chacma baboon (22\%), South African large-spotted genet (13\%) and bushpig (10\%) (Table 1). These contributions differed from those of Seydack (1984) for the Goudveld State Forest. Here, bushbuck (33\%) and South African large-spotted genet (15\%) were again important, but the contributions by chacma baboon and bushpig were small $(<6 \%)$, being surpassed by honey badger $(21 \%)$ and Cape porcupine, Hystrix africaeaustralis (16\%).

Seydack (1984) noted that honey badger showed interest in and examined the trip plates used to activate the cameras. Preliminary experiments have shown that both honey badger and Cape porcupine are attracted to objects scented with perfume (Braczkowsi 2009). The ground disturbance and smell associated with the trip plates may have attracted these species to the camera sites.

However, there are many other factors that may have influenced the capture rates. Half of the cameras used in this study were Cuddeback Capture cameras and comparative sampling, deploying the Cuddeback Capture cameras and Bushnell Trophy Cams simultaneously, resulted in the former cameras frequently failing to record small species, such as the South African large-spotted genet and marsh mongoose (Randall \& Hanekom 2014). Consequently, the values for these species were underestimates.

The ability of a camera trap to detect individual animals generally correlates to the body size of the species (Rowcliffe et al. 2011; Tobler et al. 2008). A further influencing factor was that the bright, incandescent flash of the Cuddeback Capture camera startled some of the species (e.g. bushpig), often making them camera-shy and less likely to be recaptured (Randall \& Hanekom 2014). In addition, the camera traps were not equally spaced from each other within a sampling grid, but were erected along a series of trails in each forest, usually positioned less than $300 \mathrm{~m}$ from the nearest neighbour. Consequently, not all areas of a forest site were equally sampled, the number of recaptures was high, and the data were probably biased towards those species that appear to frequent trails (e.g. caracal, bushbuck, bushpig and genet; Table 2).

Seasonal variations in animal abundance were also not evaluated, with the assessment of a forest site being restricted to a once-off trapping cycle of between 28 and 45 days. Nevertheless, it is noteworthy that both the highest and the lowest values for both capture rates and species numbers were all recorded during winter (April-September) (Sites 3-7; Table 1), suggesting that seasons were not an overriding factor in determining capture rates in this study.

In general, capture frequencies do not allow for direct interspecies comparisons (Sollmann et al. 2013). The two species most frequently captured in this study, namely bushbuck $(40 \%)$ and chacma baboon (22\%), have characteristics that enhance the likelihood of capture. The former species is a medium-size antelope with an apparent preference for utilising trails (Table 2) and a large home range that frequently overlaps with those of other individuals, allowing them to roam over other animals' home ranges (Odendaal \& Bigalke 1979). Similarly, the chacma baboon lives in fairly big troops, which have large and sometimes overlapping home ranges (Skinner \& Chimimba 2005). Consequently, these species may not be the most abundant mammals in the study area.

Koen and Crowe (1987) recorded similar bird communities and, to a lesser extent, invertebrate communities, in the dry-, moist- and wet forests of the GRNP, despite clear differences in the composition and structure of the vegetation. Likewise, in this study the number of species and the capture rates of the various taxa recorded in dry (high and scrub) forests were similar $(P>0.10)$ to those in moist (medium-moist to wet) high forests. These results support the concept that animal discrimination for vegetation structure is relatively poorly refined within tall, closed forest (Taylor, Friend \& Dudzinski 1984).

Although the median number of species and total capture rates for sites in the large Goudveld-Diepwalle forest complex were similar $(P>0.10)$ to those of the small $\left(<41 \mathrm{~km}^{2}\right)$ forests, the lowest values in this survey were recorded at three of the seven sites in the large forest complex. At species level, the capture rates of caracal and vervet monkey were significantly lower in the large forest complex than in smaller forests $(U=2.21$ and 1.98, $d f=7.4, P \leq 0.05)$ (Table 1$)$. The significance of these trends is, however, questionable, because of the small sample size. Nevertheless, over their 
distribution ranges, these two species appear to be associated more with woodlands or riparian vegetation of savannas than with forests (Skinner \& Chimimba 2005). They may use forests as a refuge, whilst also feeding in adjacent, more open areas.

In the Lopé National Park of Gabon, species richness, as well as biomass estimates for bushbuck, blue duiker, monkeys, Cercopithecus spp.; and red river hog, Potamochoerus porcus; were all lower in the continuous closed canopy forest than in smaller forest fragments (i.e. gallery forest and bosquet) (Tutin, White \& Mackanga-Missandzou 1997). Here the ecotone effect would have been greater than in continuous forests, which could have influenced the species composition (Forman, Galli \& Leck 1976). Continuous forest would, however, be important for forest-sensitive species, and studies have shown that primate richness in Asia, South America and Madagascar generally declines significantly with a decrease in forest size (Harcourt \& Doherty 2005), a trend noted for the samango monkey, Cercopithecus albogularis; in KwaZulu-Natal (Lawes, Mealin \& Piper 2000).

Three threatened and protected South African species (blue duiker, leopard and honey badger) together comprised approximately $6 \%$ of trail captures in this study (Table 1 ). Contrary to expectation, Sites 1 and 2 (on-trail) and Site 10 (off-trail) were the only trap surveys where all three of these species were recorded (Tables 1 and 2). Not only were all these surveys in small forests $\left(<41 \mathrm{~km}^{2}\right)$, but Site 1 borders the village of Wilderness and is walked extensively by day hikers.

These preliminary results suggest that small forests could play an important role in the conservation of mammal fauna in the GRNP. These forests are worthy of strict protection, especially since many of them are located on or bordering coastal areas, where substantial land transformation has occurred through agricultural, silvicultural and urban development. Of the species recorded in this study, only the blue duiker is an obligate forest species. The others are capable of utilising more open habitats (Skinner \& Chimimba 2005), and probably use the small forests largely as a refuge.

\section{Acknowledgements}

We gratefully thank the South African National Parks for financial and logistical support, various estate managers and their staff for assistance in the field, as well as Johan Baard and Nerina Kruger for help with maps and GIS analyses. We are indebted to the referees who provided detailed and constructive suggestions for improving the manuscript.

\section{Competing interests}

The authors declare that they have no financial or personal relationships which may have inappropriately influenced them in writing this article.

\section{Authors' contributions}

R.M.R. (South African National Parks) was the project leader. He, together with N.H. (South African National Parks), were responsible for experimental design and fieldwork. N.H. analysed the capture records, performed calculations and was largely responsible for the write-up.

\section{References}

Azlan, J.M. \& Lading, E., 2006, 'Camera trapping and conservation in Lambir Hills National Park, Sarawak', The Raffles Bulletin of Zoology 54(2), 469-475.

Azlan, J.M. \& Sharma, D.S.K., 2006, 'The diversity and activity patterns of wild felids in a secondary forest in Peninsular Malaysia', Oryx 40, 36-41. http://dx.doi. org/10.1017/S0030605306000147

Bond, W.J., 1981, 'Vegetation gradients in southern Cape Mountains', MSc thesis, Dept. of Botany, University of Cape Town, Cape Town.

Braczkowsi, A., 2009, 'Lentheric leopards', unpublished data, Department of Nature Conservation, Nelson Mandela Metropolitan University, George.

Chapman, S. \& Balme, G., 2010, 'An estimate of leopard population density in a private reserve in KwaZulu-Natal, South Africa, using camera-traps and capturerecapture models', South African Journal of Wildlife Research 40(2), 114-120. http://dx.doi.org/10.3957/056.040.0202

Crawford, P.B., Crawford, S.A.H. \& Crawford, R.J.M., 1983, 'Some observations on the Cape mongoose Herpestes pulverulentus in the Tsitsikamma National Park', South African Journal of Wildlife Research 13(2), 35-40.

Crawford, R.J.M., 1982, 'Water mongoose Atilax paludinosus in the Tsitsikamma Coastal National Park', Koedoe 25(1), 121. http://dx.doi.org/10.4102/koedoe. v25i1.612

Eggert, L.S., Patterson, G. \& Maldonado, J.E., 2007, 'The Knysna elephants: A population study conducted using faecal DNA', African Journal of Ecology 46(1), 19-23. http://dx.doi.org/10.1111/j.1365-2028.2007.00794.x

Fijen, A.P.M. \& Kapp, J.F., 1995, 'Swartvlei Lake catchment, Diep, Klein-Wolwe, Hoëkraal and Karatara Rivers, water management strategy, Volume 1: Present situation', Department of Water Affairs and Forestry, Pretoria.

Forman, R.T.T., Galli, A.E. \& Leck, C.F., 1976, 'Forest size and avian diversity in New Jersey woodlots with some land use implications', Oecologia (Berlin) 26, 1-8. $\mathrm{http}: / / \mathrm{dx}$.doi.org/10.1007/BF00345649

Gómez, H., Wallace, R.B., Ayala, G. \& Tejada, R., 2005, 'Dry season activity periods of some Amazonian mammals', Studies of Neotropical Fauna and Environment 40 91-95. http://dx.doi.org/10.1080/01650520500129638

Goulart, F.V.B., Cáceres, N.C., Graipel, M.E., Tortato, M.A., Ghizoni, I.R. Jr \& OlivieraSantos, L.G.R., 2009, 'Habitat selection by large mammals in a southern Brazilian Atlantic Forest', Mammalian Biology - Zeitschrift für Säugertierkunde 74(3), 182190. http://dx.doi.org/10.1016/j.mambio.2009.02.006
10.

Hanekom, N. \& Wilson, V., 1991, 'Blue duiker Philantomba monticola densities in the Tsitsikamma National Parks and probable factors limiting these populations', Koedoe 34(2), 107-120. http://dx.doi.org/10.4102/koedoe.v34i2.427

Harcourt, A.H. \& Doherty, D.A., 2005, 'Species-area relationships of primates in tropical forest fragments: A global analysis', Journal of Applied Ecology 42, 630637. http://dx.doi.org/10.1111/j.1365-2664.2005.01037.x

Hayward, M.W., White, R.M., Mabandla, K.M. \& Bukeye, P., 2005, 'Mammalian fauna of indigenous forest in the Transkei region of South Africa: An overdue survey', South African Journal of Wildlife Research 35(2), 117-124.

Jácomo, A.T., Silveira, A.L. \& Diniz-Filho, J.A.F., 2004, 'Niche separation between the maned wolf (Chrysocyon brachyurus), the crab-eating fox (Dusicyon thous) and the hoary fox (Dusicyon vetulus) in central Brazil', Journal of Zoology 262(1), 99106. http://dx.doi.org/10.1017/S0952836903004473

Karanth, K.U. \& Nichols, J.D., 1998, 'Estimation of tiger densities in India using photographic captures and recaptures', Ecology 79(8), 2852-2862. http://dx.doi. org/10.1890/0012-9658(1998)079[2852:EOTDII]2.0.CO;2

Karanth, K.U., Nichols, J.D., Kumar, N. S. \& Hines, J.E., 2006, 'Assessing tiger population dynamics using photographic capture-recapture sampling', Ecology 87(11), 29252937. PMID: 17168036. http://dx.doi.org/10.1890/0012-9658(2006)87[2925:ATP DUP]2.0.CO;2

Kelly, M.J., Noss, A.J., Arispe, L.R., Di Bitetti, M.S., Maffe, L., Arispe, R.L. et al., 2008, 'Estimating puma densities from remote cameras across three study sites: Bolivia, Argentina, and Belize', Journal of Mammalogy 89(2), 408-418. http://dx.doi. org/10.1644/06-MAMM-A-424R.1

Koen, J.H. \& Crowe, T.M., 1987, 'Animal-habitat relationships in the Knysna Forest, South Africa: Discrimination between forest types by birds and invertebrates', Oecologia (Berlin) 72, 414-422. http://dx.doi.org/10.1007/BF00377573

Kruger, A.C., 2007, 'Climate of South Africa, Precipitation', WS46, South African Weather Service, South Africa.

Kucera, T.E. \& Barrett, R.H., 2011, 'A history of camera trapping', in A.F. O'Connell, J.D. Nichols \& K.U. Karanth (eds.), Camera traps in animal ecology: Methods and analyses, pp. 97-118, Springer, New York, NY.

Lawes, M.J., Mealin, P.E. \& Piper, S.E., 2000, 'Patch occupancy and potential metapopulation dynamics of three forest mammals in fragmented Afromontane Forest in South Africa', Conservation Biology 14(4), 1088-1098. http://dx.doi. org/10.1046/j.1523-1739.2000.99120.x 
Mucina, L. \& Rutherford, M.C. (eds.), 2006, 'The vegetation of South Africa, Lesotho and Swaziland. Strelitzia 19', South African National Biodiversity Institute, Pretoria.

Odendaal, P.B. \& Bigalke, R.C., 1979, 'Home range and groupings of bushbuck in the southern Cape', South African Journal of Wildlife Research 9(3/4), 96-101.

Randall, R.M. \& Hanekom, N., 2014, 'Comparative camera trapping records', unpublished data, South African National Parks, Wilderness National Park, Wilderness.

Robinson, G.A., 1976, 'Notes on mammals encountered in the Tsitsikama National Parks', Koedoe 19(1), 145-152. http://dx.doi.org/10.4102/koedoe.v19i1.1188

Rowcliffe, J.M., Carbone, C., Jansen, P.A., Kays, R. \& Kranstauber, B., 2011, 'Quantifying the sensitivity of camera traps: An adapted distance sampling approach', Method in Ecology and Evolution 2(5), 464-476. http://dx.doi.org/10.1111/j.2041 210X.2011.00094.X

Seydack, A.H.W., 1984, 'Application of a photo-recording device in the census of larger rain-forest mammals', South African Journal of Wildlife Research 14(1), 10-14.

Seydack, A.H.W. \& Bigalke, R.C., 1992, 'Nutritional ecology and life history tactics in the bushpig (Potamochoerus porcus): Development of an interactive model', Oecologia (Berlin) 90, 102-112. http://dx.doi.org/10.1007/BF00317815

Seydack, A.H.W., Huisamen, J. \& Kok, R., 1998, 'Long-term antelope population monitoring in Southern Cape Forests', Southern African Forestry Journal 182, 9-19. http://dx.doi.org/10.1080/10295925.1998.9631185

Seydack, A.H.W., Vermeulen, C. \& Huisamen, J., 2000, 'Habitat quality and the decline of an African elephant population: Implications for conservation', South African Journal of Wildlife Research 30(1), 34-42.

Silveira, L., Jácomo, A.T.A. \& Diniz-Filho, J.A.F., 2003, 'Camera trap, line transect census and track surveys: A comparative evaluation', Biological Conservation 114, 351355. http://dx.doi.org/10.1016/S0006-3207(03)00063-6

Skinner, J.D. \& Chimimba, C.T., 2005, The mammals of the Southern African Subregion, 3rd edn., Cambridge University Press, Cambridge.
Sollmann, R., Mohamed, A., Samejima, H. \& Wilting, A., 2013, 'Risky business or simple solution - Relative abundance indices from camera-trapping', Biological Conservation 159, 405-412. http://dx.doi.org/10.1016/j.biocon.2012.12.025

Srbek-Araujo, A. C. \& Chiarello, A. G., 2005, 'Is camera-trapping an efficient method for surveying mammals in Neotropical forests? A case study in south-eastern Brazil', Journal of Tropical Ecology 21(1), 121-125. http://dx.doi.org/10.1017/ S0266467404001956

STSC, Inc., 1989, STATGRAPHICS, Statistical Graphics System, Version 4.0, Statistical Graphics Corporation, Maryland.

Taylor, J.A., Friend, G.R. \& Dudzinski, M.L., 1984, 'Influence of sampling strategy on the relationships between fauna and vegetation structure, plant lifeform and floristics', Australian Journal of Ecology 9(3), 281-287. http://dx.doi. org/10.1111/j.1442-9993.1984.tb01364.x

Tobler, M.W., Carrillo-Percastegui, S.E., Leite Pitman, R., Mares, R. \& Powell, G. 2008 , 'An evaluation of camera traps for inventorying large- and medium-sized terrestrial rainforest mammals', Animal Conservation 11(3), 169-178. http:// dx.doi.org/10.1111/j.1469-1795.2008.00169.x

Trolle, M., 2003, 'Mammal survey in the southeastern Pantanal, Brazil', Biodiversity and Conservation 12(4), 823-836. http://dx.doi.org/10.1023/A:1022489426920

Tutin, C.E.G., White, L.J.T. \& Mackanga-Missandzou, A., 1997, 'The use by rain forest mammals of natural forest fragments in an equatorial African savanna', Conservation Biology 11(5), 1190-1203. http://dx.doi.org/10.1046/j.1523-1739.1997.96211.x

Van Daalen, J.C., 1984, 'Distinguishing features of forest species on nutrient-poor soils in the Southern Cape', Bothalia 15(1/2), 229-239. http://dx.doi.org/10.4102/abc v15i1/2.1123

Von Breitenbach, F., 1974, Southern Cape forests and trees, Government Printers, Pretoria.

Whitfield, A.K., Allanson, B.R. \& Heinecken, T.J.E., 1983, 'Estuaries of the Cape, Report No. 22: Swartvlei (CMS 11)', CSIR, Stellenbosch.

Zar, J.H., 1984, Biostatistical analysis, 2nd edn., Prentice Hall, Englewood Cliffs, New Jersey. 